\title{
Sustainable Development Policy: Goals, Targets and Political Cycles
}

\author{
Nuno Quental, ${ }^{1 *}$ Júlia M. Lourenço ${ }^{2 *}$ and Fernando Nunes da Silva' \\ ${ }^{1}$ Instituto Superior Técnico, CESUR, Lisboa, Portugal \\ ${ }^{2}$ University of Minho, Department of Civil Engineering, Guimarães, Portugal
}

\begin{abstract}
This paper describes the global political milestones of greater importance to the emergence and evolution of sustainable development. In addition, it depicts the cyclical patterns of political activity dealing with sustainability and identifies the main sustainability goals and targets endorsed by several political initiatives. These tasks are accomplished through a literature review and an assessment of indicators dealing with political will. It is concluded that global sustainability governance followed an intermittent path characterized by two periods of significant accomplishments (until 1979; 1987-1995) and by two others less successful (1980-1986; 1995 onwards, interrupted by a peak around 2000). Peaks in political activity coincide with the decennial Earth Summits, suggesting their major influence as catalysts of more profound societal and political action. Sustainability concerns and goals shifted from an emphasis on pollution control and availability of natural resources to a more balanced position that puts human development at the center. Copyright (C) 2009 John Wiley \& Sons, Ltd and ERP Environment.
\end{abstract}

Received 23 December 2008; revised 27 February 2009; accepted 6 March 2009

Keywords: sustainable development; sustainability; sustainability science; environmental policy; goals; targets

\section{Acronyms}

CBD: Convention on Biological Diversity

CITES: Conference on International Trade in Endangered Species of Wild Fauna and Flora

CLRTAP: Convention on Long-Range Transboundary Air Pollution

CMS: Convention on the Conservation of Migratory Species of Wild Animals

GEF: Global Environment Facility

IUCN: International Union for the Conservation of Nature

OECD: Organization for Economic Co-operation and Development

UNCCD: United Nations Convention to Combat Desertification

UNCED: United Nations Conference on Environment and Development

UNCHE: United Nations Conference on the Human Environment

UNCSD: United Nations Commission on Sustainable Development

*Correspondence to: Nuno Quental/Júlia M. Lourenço, Universidade do Minho, Departamento de Eng. Civil, Campus de Azurém, $4800-058$ Guimarães, Portugal. E-mail: quental.nuno@gmail.com 
UNDSD: United Nations Division for Sustainable Development

UNEP: United Nations Environment Programme

UNFCCC: United Nations Framework Convention on Climate Change

WCED: World Commission on Environment and Development

WCS: World Conservation Strategy

WHC: World Heritage Convention

WSSD: World Summit on Sustainable Development

\section{Introduction}

T

HE INTRODUCTION OF SUSTAINABLE DEVELOPMENT AS A CONCEPT WAS AN INTELLECTUAL ANSWER TO RECONCILE THE conflicting goals of environmental protection and economic growth. Sustainability gained wide acceptance after the publication of the Brundtland Commission's report Our Common Future, whose blurred definition is the most commonly cited in the literature (Quental et al., submitted for publication). This much debated idea proclaims almost a utopia of a society where no obvious concessions are necessary. The fact that such conflicts are usually disregarded by policy-makers does not mean that they do not exist (Skowronski, 2008; Leiserowitz et al., 2006). In fact, quite the opposite is true: while a profound and democratic discussion about the most cutting issues of sustainable development is postponed, tacit and often little scrutinized decisions are taken every day. Understanding the implications in terms of sustainability of the different policy options available and making explicit the usually less documented trade-offs between compelling goals that each policy option implies are therefore much needed tasks.

Although many authors argue that the practice of sustainable development is still in its infancy, as real outcomes are yet to be seen on a global level (e.g. Morse, 2008; MEA, 2005; Kates and Parris, 2003; WRI, 2003, p. I45), Kates et al. (2005) contend that in the past 40 years the environment has become a key focus of national and international law and institutions.

The present paper attempts to describe the political milestones at the global level of greater importance to the emergence and evolution of sustainable development as an ideal, and to depict the cyclical patterns of this political activity. In addition, this research aims at identifying the main sustainability goals and targets endorsed by such political initiatives. These tasks are accomplished by referring to and discussing relevant meetings, agreements and declarations by way of a brief literature review, and by an assessment of indicators dealing with political will such as the signature and ratification of environmental agreements, the creation of protected areas, the establishment of environmental ministries and the expenditure on environmental protection.

The combined use of the literature review - where judgments concerning the relative importance of different political events had to be made - and the objective standpoint conveyed by the indicator analysis allowed a more robust assessment and a graphical representation of the evolution of political activity, as intended.

The selection of the most relevant political initiatives is a difficult and subjective task since no easily accessible indicators to measure regime effectiveness have emerged. Scholars have been under a lively debate to discuss the issue (see, for instance, Mitchell, 2006; Underdal and Young, 2004; Mitchell, 2003; Miles et al., 200I; Helm and Sprinz, 2000; Young, I999). Most of the frameworks for analysis opt for several factors that should be interpreted through contextual approaches. According to Mitchell (2003, p. 449), countries that are ecologically vulnerable and have low adjustment costs tend to be more responsive to agreements, while those that are not affected ecologically or have high adjustment costs tend to be more recalcitrant. Selin and Linnér (2005) structured global cooperation and policy making on the integration of environment and development around four perspectives: the emergence and influence of an international environment and development discourse, the growing multilateralism and the building of new international institutions, the power politics and the North-South conflicts. In order to circumvent the difficulty of determining which political milestones were decisive for sustainable development, this paper adopts those most commonly referred to in the literature as such.

Although syntheses regarding sustainable development have already been published, their foci differ from the one presented in this paper. For instance, Pawlowski (2008) described several dimensions of sustainability that are often neglected. Leiserowitz et al. (2006) surveyed five major efforts to identify values and 
behaviors essential for a sustainability transition. They also analyzed how contextual trends (freedom and democracy, capitalism, globalization and equality) could influence societal ability to adopt these values, attitudes and behaviors. Parris and Kates (2003a) characterized specific goals, targets and associated indicators as embodied in international agreements and plans of action, and the current state and efforts to attain four such goals (reducing hunger, promoting literacy, stabilizing greenhouse-gas concentrations and maintaining fresh-water availability). Parris and Kates $(2003 \mathrm{~b})$ highlighted similarities and differences in the motivation, process and technical methods used in a dozen prominent examples of sets of sustainability indicators. They concluded that no indicator sets are universally accepted, backed by compelling theory, rigorous in data collection and analysis and influential in policy. Goodland (I995), in turn, analyzed the scientific dimension of environmental sustainability, namely the implications in terms of growth, limits, scale and capital substitutability. These papers share with the present text strong relationships, but it is intended to expand their results offering a robust synthesis of the sustainable development goals and milestones in a historical perspective through the integration of both qualitative and quantitative information.

\section{Methodology}

The evolution of sustainable development policy presented in this paper is divided into two main parts: a literature review and an indicator based assessment.

The literature review was carried out in order to identify and describe the milestones of sustainable development policy since the Ig6os, and the goals and targets they endorse. A tentative list of these milestones (multilateral agreements, institutional arrangements, conferences and documents) was compiled drawing from UNEP (2008, 2007, p. 379), Ginn (2008), WRI (2007), IISD (2007), Selin and Linnér (2005), WRI (2003, pp. I46-I47), Runyan and Norderhaug (2002), UNEP (2002, pp. 2-26), UNEP (200I, pp. I3-I5) and D'Amato and Engel (I997). The identification of sustainability goals and targets resulted from the content analysis of relevant declarations ('soft law'), conferences' agendas and scientific literature (Leiserowitz et al., 2006, and Paris and Kates, 2003a, 2003b, were particularly useful).

Data that could serve as a proxy of sustainable development policy and capable of depicting the patterns of political activity were gathered. Five indicators were used for this purpose: the number of new parties to multilateral environmental agreements as registered by WRI (2007); the number of environmental agreements, amendments and protocols signed according to Mitchell (2008); the number of protected areas created (UNEP and IUCN, 2007); the number of environmental ministries established (Sélin and Linnér, 2005) and the government expenditure on environmental protection (OECD, 2008). Mitchell (2003, p. 432) defines an international environmental agreement as an 'intergovernmental document intended as legally binding with a primary stated purpose of preventing or managing human impacts on natural resources'. These are reliable indicators cited in respectable publications (e.g. Sélin and Linnér, 2005; WRI, 2003; UNEP, 2002), but they were also the only ones available at a global or regional level with a convenient time coverage.

Data concerning environmental expenditures were available from OECD (2008) on a country basis and as national currencies at current prices. Data gaps were large before 1996 , potentially leading to inconsistent results. To avoid this misleading effect, values prior to 1996 were discarded and the remainder was converted to Euros at the exchange rate as of I8 December 2008. For each year, a weighed per capita average for the whole set of countries (Austria, Belgium, Canada, Denmark, Finland, France, Germany, Italy, Japan, Netherlands, Norway, Spain, Sweden and United Kingdom) was calculated.

To facilitate comparisons between variables - as units and scales were highly diverse - an index was computed in such a way that, for each indicator, zero was made to correspond to its minimum value and Ioo to its maximum. Then, in order to smooth the lines and avoid their excessive yearly fluctuation, data were averaged on a three year basis, i.e., each point represents the average between the values of the previous, current and following years.

The Fletcher database (Ginn, 2008) was used to characterize the primary topics covered by multilateral agreements. This source was favored instead of Mitchell (2008) because of its higher selectivity (only the most relevant agreements are listed) but broader thematic scope (human rights and cultural protection agreements are included, in contrast to Mitchell's database, which deals only with environmental agreements). 


\section{International Politics and Policy}

The following sections review the main developments of sustainable development policy according to a cycling framework consisting of four main stages. Although the most important milestones are referred to in the text, Table I compiles from several sources a larger set of political achievements.

\section{Until the End of the 1970s: the First Steps}

Environmental discourse grew slowly from the i950s triggered by worsening socio-economic and ecological conditions. Kirkby et al. (I999, pp. 2-6) refer to a development crisis characterized by escalating poverty and social inequalities, a security crisis driven by the nuclear race and by several post-colonial wars and an environmental crisis fed by concerns such as toxic pollution, health effects of thalidomide, the death of Nordic lakes and the rising world population. Pioneering efforts led to the creation of the now International Union for the Conservation of Nature (IUCN) in I948, the United Nations Scientific Conference on the Conservation and Utilization of Resources in I949, the World Population Conferences in I954 and I964 and the Biosphere Conference in I968.

The United Nations Conference on the Human Environment (UNCHE) was held in Stockholm in June I972 and is usually credited as a fundamental catalyst for international awareness of the Earth's environment and development problems (UNEP, 2002, p. 4; Kates et al., 2005). Built around the René Dubos and Barbara Ward book Only One Earth, and attended by 132 member states of the United Nations - but missed by the former USSR and most of its allies due to the Cold War divide, the conference had important outcomes, which extended throughout the I970s and beyond. Three agreements were reached: the Stockholm Declaration with 26 principles, which constituted the first body of soft law in international environmental affairs; an action plan of rog recommendations and five issue-specific resolutions.

While the declaration coherently merged the North's aspirations of environmental sustainability with the South's goal of achieving development, which were very much at the center of the debate, ('poverty is the worst form of pollution', as the Indian Prime Minister Indira Ghandi put it), the action plan enriched and complemented it. Decisions regarding the creation of the United Nations Environment Programme (UNEP) and of an environmental fund, among others, were taken through the resolutions (Selin and Linnér, 2005). Principles and rights taken for granted nowadays in legal and cultural frameworks, such as the right to live in an environment of quality and the principle of compensating other nations when transboundary impacts occur, were devised in Stockholm, albeit more controversial issues such as the principle of national sovereignty remained unchanged.

During the I970s, a number of key multilateral environmental agreements were achieved. They include the Ramsar Convention on Wetlands of International Importance (I97I), the World Heritage Convention (WHC) (I972), the Convention on the Prevention of Marine Pollution by Dumping of Wastes and Other Matter (I972), the Conference on International Trade in Endangered Species of Wild Fauna and Flora (CITES) (I973), the Convention on the Conservation of Migratory Species of Wild Animals (I979) and the Convention on Long-Range Transboundary Air Pollution (CLRTAP) (I979). Indirect outcomes at the national level involved the growing designation of national parks, the approval of several environmental protection laws and the creation of environmental ministries (Selin and Linnér, 2005; Soromenho-Marques, 2005, p. 47; D’Amato and Engel, I997, p. 3) - see also below. Scientific advancements such as the understanding of climate change, the mechanisms behind the ozone hole (although only confirmed in I985) and the problem of desertification helped, along with the Stockholm Conference, to increase environmental awareness.

\section{0-1986: a Stagnation Period}

In I974, the symposium on Patterns of Resource Use, Environment and Development Strategies took place in Cocoyoc, Mexico, in order to debate the social and economical causes of environmental degradation. Its declaration contains several statements that could well be today's: 'The first point to be underlined is that the failure of world society to provide "a safe and happy life" for all is not caused by any present lack of physical resources. The problem today is not primarily one of absolute physical shortage but of economic and social maldistribution and misuse'. 


\begin{tabular}{|c|c|c|c|}
\hline Year*' & Name & Type* & Theme \\
\hline 1964 & World Population Conference & C & (Various) \\
\hline 1966 & International Covenant on Economic, Social and Cultural Rights & M & Human rights \\
\hline 1966 & International Covenant on Civil and Political Rights & M & Human rights \\
\hline 1968 & Biosphere Conference & C & Biodiversity \\
\hline 1971 & Ramsar Convention on Wetlands of International Importance & M & Ecosystems \\
\hline 1972 & United Nations Conference on the Human Environment & $\mathrm{C}$ & (Various) \\
\hline 1972 & UNEP & I & Governance \\
\hline 1972 & $\begin{array}{l}\text { Convention Concerning the Protection of the World Cultural and } \\
\text { Natural Heritage }\end{array}$ & M & Cultural protection \\
\hline 1973 & Convention on International Trade in Endangered Species (CITES) & $\mathrm{M}$ & Biodiversity \\
\hline 1973 & Convention for the Prevention of Pollution from Ships & M & Waste, chemicals and pollution \\
\hline 1974 & $\begin{array}{l}\text { Symposium on Patterns of Resource Use, Environment and } \\
\text { Development Strategies (Cocoyoc, Mexico) }\end{array}$ & C & (Various) \\
\hline 1976 & United Nations Conference on Human Settlements & C & (Various) \\
\hline 1979 & Bonn Convention on Migratory Species & M & Biodiversity \\
\hline 1979 & $\begin{array}{l}\text { Convention on the Conservation of Migratory Species of Wild } \\
\text { Animals }\end{array}$ & M & Biodiversity \\
\hline 1979 & Convention on Lang-Range Transboundary Air Pollution & M & Waste, chemicals and pollution \\
\hline 1980 & World Conservation Strategy & D & Ecosystems \\
\hline 1982 & United Nations Convention on the Law of the Seas & $\mathrm{M}$ & Ecosystems \\
\hline 1982 & World Charter for Nature & $\mathrm{D}$ & Ecosystems \\
\hline 1985 & Vienna Convention for the Protection of the Ozone Layer & $\mathrm{M}$ & Waste, chemicals and pollution \\
\hline 1987 & Montreal Protocol on Substances that Deplete the Ozone Layer & $\mathrm{M}$ & Waste, chemicals and pollution \\
\hline 1987 & $\begin{array}{l}\text { Basel Convention on the Transboundary Movement of Hazardous } \\
\text { Wastes }\end{array}$ & M & Waste, chemicals and pollution \\
\hline 1987 & Our Common Future & $\mathrm{D}$ & (Various) \\
\hline 1988 & Intergovernmental Panel on Climate Change & 1 & Waste, chemicals and pollution \\
\hline 1992 & United Nations Conference on Environment and Development & C & (Various) \\
\hline 1992 & United Nations Commission on Sustainable Development & 1 & Governance \\
\hline 1992 & Convention on Biological Diversity & M & Biodiversity \\
\hline 1992 & United Nations Framework Convention on Climate Change & M & Waste, chemicals and pollution \\
\hline 1992 & Agenda 21 & $\mathrm{D}$ & (Various) \\
\hline 1993 & World Conference on Human Rights & C & Human rights \\
\hline 1994 & Conference on Population and Development & C & (Various) \\
\hline 1994 & Global Environment Facility & 1 & Governance \\
\hline 1994 & United Nations Convention to Combat Desertification & M & Ecosystems \\
\hline 1995 & World Summit for Social Development & C & (Various) \\
\hline 1995 & Conference on Women & C & Human rights \\
\hline 1997 & Kyoto Protocol & M & Waste, chemicals and pollution \\
\hline 1998 & $\begin{array}{l}\text { Aarhus Convention on Access to Information, Public Participation in } \\
\text { Decision-Making and Access to Justice in Environmental Areas }\end{array}$ & M & Governance \\
\hline 1998 & Rotterdam Convention on Prior Informed Consent & M & Waste, chemicals and pollution \\
\hline 2000 & Second World Water Forum & C & Ecosystems \\
\hline 2000 & Cartagena Protocol on Biosafety & M & Biodiversity \\
\hline 2000 & Millennium Summit and Millenium Declaration & C, D & (Various) \\
\hline 2001 & Stockholm Convention on Persistent Organic Pollutants & M & Waste, chemicals and pollution \\
\hline 2002 & World Summit on Sustainable Development & C & (Various) \\
\hline 2005 & World Summit & C & (Various) \\
\hline
\end{tabular}

Table 1. Sustainable development political milestones since the $1960 \mathrm{~s}$

* Dates refer to the year in which multilateral agreements (M) were signed, conferences (C) were organized, institutions (I) were established or documents or declarations (D) were issued. 
The declaration called UNEP to pursue efforts of 'eco-development'. Although conceptually equivalent to the now ubiquitous concept of 'sustainable development', the former never received much attention (Selin and Linnér, 2005).

During the I980s, social inequalities were exacerbated in several developing countries through the implementation of the Washington Consensus policies (Kirkby et al., I999). Trade liberalization, tax reforms and privatization of public services that followed often broke local institutions, leading to massive natural resource exploitation (Dasgupta, 200I). The number of war refugees doubled from about 9 million in I980 to more than I 8 million by the early I990s (UNEP, 2002, p. 8). Famine spread through large parts of Africa, killing in Ethiopia more than I million people between I984 and I985. The attention of the international community shifted to economic growth as a solution for poverty and social inequalities that was thought to be compatible with environmental improvements (Röpke, 2005, p. 268). Security issues also played a pivotal role because of the Cold War (Selin and Linnér, 2005 , p. 42). The world experienced serious environmental accidents: in I984, a toxic cloud leaked from a Union Carbide plant in Bhopal, India; in I986, a nuclear reactor at the Chernobyl power plant exploded, releasing a radioactive cloud that floated over Russia and part of Europe; three years later, the tanker Exxon Valdez spilled 50 million liters of oil in Alaska's Prince William Sound.

Besides the stagnation of global environmental policy, sustainable development, or more specifically environmental sustainability, was emphasized by the World Conservation Strategy (WCS) (Kirkby et al., I999). Jointly devised by IUCN, UNEP and the World Wide Fund, and launched simultaneously in 35 countries in I980, the strategy sought to maintain essential ecological processes, to preserve genetic diversity and to ensure the rational use of species and ecosystems (Adams, 2006). Curiously, although pushing for sustainability, the strategy found it to be compatible with economic growth (Goodland, I995, p. 9). An update of the document entitled Caring for the Earth: a Strategy for Sustainable Living was issued in I991. Moreover, the United Nations General Assembly approved in I982 the World Charter for Nature, celebrated the Stockholm Conference's anniversary (the so-called 'Stockholm +IO', even though it took place in Nairobi) and approved the United Nations Convention on the Law of the Sea.

\section{7-1995: Major Achievements}

The beginning of a new growth period in global sustainable development policy was marked by the accomplishments of the World Commission on Environment and Development (WCED). The commission was set up by the General Assembly of the United Nations in I982 as an 'independent' group of high level experts and government officials chaired by the then Prime Minister of Norway Gro Harlem Brundtland. The commission was asked to formulate a 'global agenda for change' and, more specifically, to 'propose long-term environmental strategies for achieving sustainable development by the year 2000 and beyond' (WCED, I987). The report Our Common Future, released in 1987 after three years of public hearings, is the most cited document in the sustainable development literature (see below). Being able to reconcile the environmental interests of the North with the development needs of the South, the commission effectively joined the world through the catchphrase 'sustainable development'. The concept, defined as 'meeting the needs of the present generation without compromising the ability of future generations to meet their own needs', although stated with a similar meaning as far back as I979 (as can be checked through a search in Mitchell, 2008), became popular only after Brundtland's work (Selin and Linnér, 2005).

The report explored the factors behind the growing equity gap between the rich and the poor and issued guidance so that sustainable development could be integrated into countries' policies. These ranged through asking for more growth, to conserve and enhance the resource base, ensure a sustainable level of population, reorient technology, integrate environmental concerns into decision-making and strengthen international cooperation (WCED, I987). The publication of the report prompted a strong international awareness of the sustainability issues, which, inter alia, contributed to the perceived success of both the Rio Summit in 1992 and its affiliated documents (Kirkby et al., I999, p. I).

Some of the commission's statements were rather controversial. For instance, the appeal for a sustainable economic growth is at odds, according to Daly (I996), with sustainable development. However, it is important to bear in mind the procedural and political contexts under which the report was prepared, which probably prevented the commission from refining all discrepancies and led to what Kirkby et al. (I999, p. 9) called 'irreconcilable 
positions'. Alternatively, it may be that the commission truly believed that the growth limits were only technical, cultural and social (Kirkby et al., I999, p. 7), dismissing the biophysical limits that nowadays seem very present. Brundtland's original call for a ' 5 to Io-fold more growth' was rectified and reversed in I992 by placing population higher on the agenda of sustainability (Goodland, I995, p. 9).

The progress of international governance was patent through the signature of the Montreal Protocol on Substances that Deplete the Ozone Layer (I987) and of the Basel Convention on the Control of Transboundary Movements of Hazardous Wastes and their Disposal (I989), as well as through the creation of the International Panel on Climate Change (I988) and of the Global Environment Facility (GEF) (I99I). At the same time, the I990s, which started with the social and environmental catastrophe of the Gulf War, witnessed the loosening of trade rules, especially after the establishment in 1995 of the World Trade Organization.

The positive context referred to by Conca (2007, p. I25), partially as a result of the end of the cold war, helps explain why the expectations were so high at the United Nations Conference on Environment and Development (UNCED) in I992. More than Ioo chiefs of state, I400 non-governmental organizations, 9000 journalists and a total of 30000 people participated in the conference (UNEP, 2002, p. I5). Although divergences between North and South were present - leading to a 'greener agenda' and a mismatch when compared with the more balanced outcomes of the Brundtland report (Kirkby et al., I999) - the results can be considered a success: two international agreements (the United Nations Framework Convention on Climate Change (UNFCCC), the Convention on Biological Diversity (CBD) and, in I994, the United Nations Convention to Combat Desertification (UNCCD)), a 40 chapter long blueprint for sustainable development called Agenda 2I, the 27 principles of the Rio Declaration on Environment and Development, the creation of the United Nations Commission on Sustainable Development (UNCSD) and the non-binding Principles for the Sustainable Management of Forests. Despite all these accomplishments, no agreement was reached regarding a universal Earth Charter that could guide the transition to sustainable development.

The Rio Declaration reaffirmed the main issues addressed by the Stockholm Declaration. Its first principle expresses an inspired view about human life: 'Human beings are at the centre of concerns for sustainable development. They are entitled to a healthy and productive life in harmony with nature'.

\section{Retrogressing in the New Millennium}

During September 2000 the heads of state gathered at the United Nations hosted Millennium Summit to discuss a broad agenda that covered both development and environmental concerns. The meeting resulted in the Millennium Declaration, which stressed freedom, equality, solidarity, tolerance, respect and shared responsibility as the essential values governing international relations in the $2 \mathrm{I}^{\text {st }}$ century, and resulted in several global targets called Millennium Development Goals. These comprise, among others, halving poverty, halving the proportion of people without access to safe drinking water, halting the spread of AIDS and insuring universal primary school education, all of them by 2015 .

The follow-up of the Rio Earth Summit took place in Johannesburg in 2002. The World Summit on Sustainable Development (WSSD), attended by over roo heads of state and close to 25000 different organizations, is still considered the largest event organized by the United Nations (Wapner, 2003). Along with the main sessions a number of parallel events arranged by civil society took place. As usual, the summit resulted in a declaration and a more detailed plan of implementation.

The main goal of the summit was to put in place the necessary mechanisms to implement Rio's decisions, since progress during the Io year interval had been disappointing (see, e.g., MEA, 2005; Parris and Kates, 2003a; Kates and Parris, 2003). The conference is considered a flop in that it generally recalled the targets already established during the Millennium Summit. The world was not able to pursue more stringent commitments. Wapner (2003) blames September II and the world's concern with the terrorism threat, adding that the old principle of requiring environmental protection in the North and asking for development aid in the South was overruled by the belief that economic globalization was a cure for all problems. In fact, care was taken to avoid embarrassing contradictions between trade and environmental agreements. At the same time, some Southern countries started to realize that their natural resources could be a major source of welfare if carefully managed and that ruthless free trade might jeopardize them. Conca (2007) and Redclift (2006) argue that the neoliberal ideology pursued by most 
countries is characterized by a smaller degree of institutionalization, which motivated the expansion of the human rights and the environmental protection movements. Conclusions regarding the weaker outcomes of WSSD, although they may prove correct, may be due to an increasing responsibility and role played by civil society. This is visible, for example, in the 344 partnerships between governments, industry and non-governmental organizations established since the Johannesburg conference to carry out sustainability actions (UNDSD, 2008b). Haas (2004) adds that a new complex decentralized international governance system is emerging. It is characterized by a multitude of actors working at various levels. Hence, relying solely on governmental actions in the analysis of societal efforts for a sustainability transition is a reductionist and misleading approach.

Still, global environmental policy experienced significant accomplishments in regulating specific threats arising from technological developments. This is the case of the 2000 Protocol on Biosafety and the 200I Stockholm Convention on Persistent Organic Pollutants. Earlier, in I997, world leaders signed the Kyoto Protocol, but it was not until 2005 that it entered into force.

\section{Metrics of Political Activity}

\section{Policy Cycles}

Global political activity concerning sustainable development followed an intermittent path characterized by periods of significant accomplishments and by others less successful. Figure i depicts this cycling pattern through the use of data indicating political will (refer to Table 2 for some descriptive statistics about these indicators).

Although a careful analysis of each of the indicators represented in Figure I is beyond the scope of this paper, since the intention is to depict cycles of political activity from their joint interpretation, some interesting results are worth mentioning. Between UNCHE and UNCED, the rate of agreements, amendments and protocols was

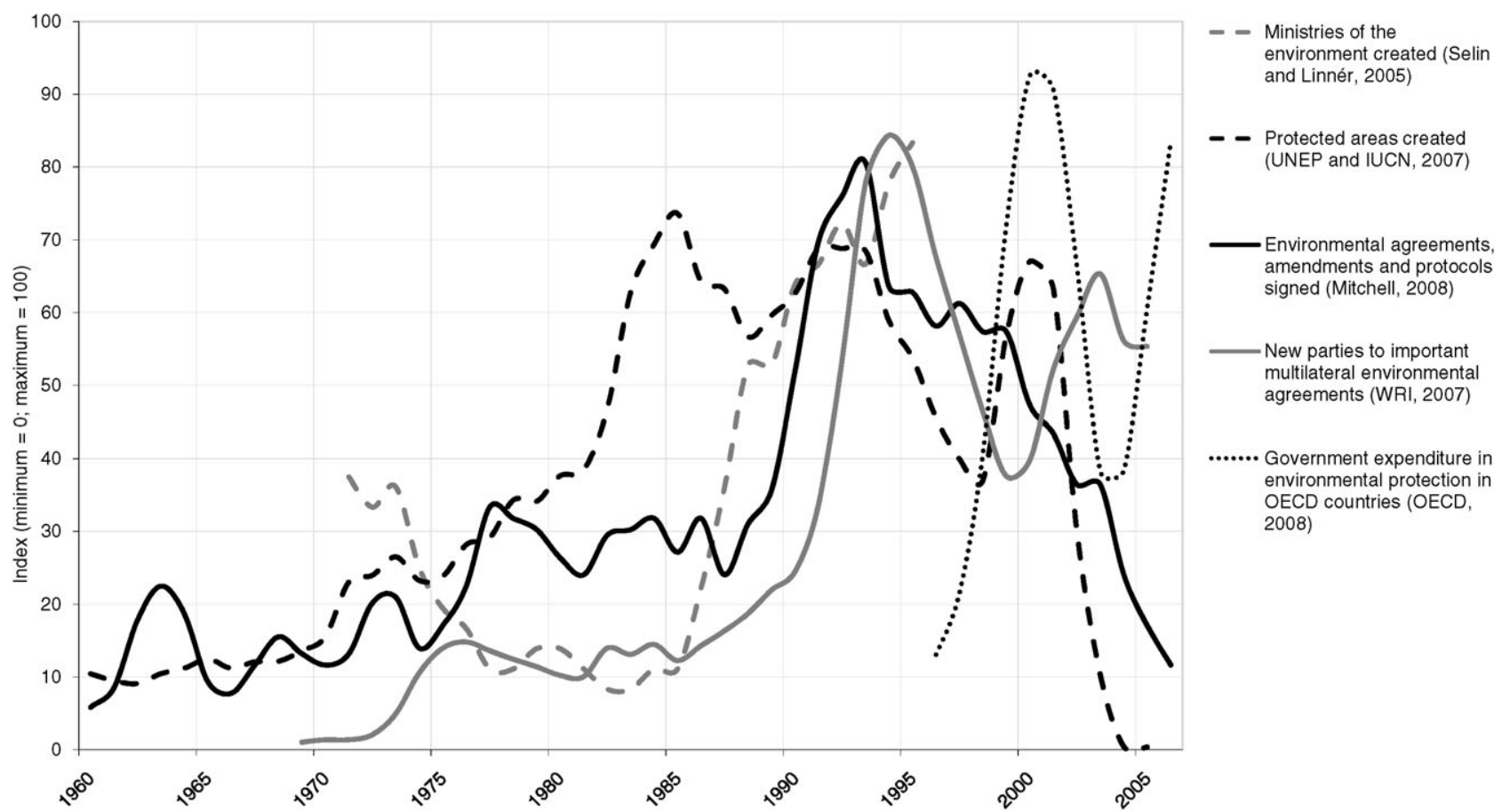

Figure 1. Indicators reflecting the evolution of sustainable development political activity. Source: own work based on references cited 


\begin{tabular}{|c|c|c|c|c|c|}
\hline $\begin{array}{l}\text { Ministries of the environment } \\
\text { created }\end{array}$ & Selin and Linnér, 2005 & O & 12 & 4.1 & Number \\
\hline Protected areas created & UNEP and IUCN, 2007 & 238 & 3562 & 1450 & Number \\
\hline $\begin{array}{l}\text { Environmental agreements, } \\
\text { amendments and protocols } \\
\text { signed }\end{array}$ & Mitchell, 2008 & 4 & 47 & 17.4 & Number \\
\hline $\begin{array}{l}\text { New parties to important } \\
\text { multilateral environmental } \\
\text { agreements }\end{array}$ & WRI, 2007 & 1 & 197 & $57 \cdot 3$ & Number \\
\hline $\begin{array}{l}\text { Government expenditure in } \\
\text { environmental protection in } \\
\text { some OECD countries* }\end{array}$ & OECD, 2008 & 235 & 250 & 244 & Euros per capita \\
\hline
\end{tabular}

Table 2. Comparison of sustainable development agendas, goals and targets as expressed in selected conferences, declarations and publications. The table draws from Leiserowitz et al. (2006), Selin and Linnér (2005) and Kirkby et al. (1999)

*Austria, Belgi um, Canada, Denmark, Finland, France, Germany, Italy, Japan, Netherlands, Norway, Spain, Sweden and United Kingdom.

around I7 per year. This rate increased significantly to around 30 until WSSD (see also Mitchell, 2003, p. 438). A similar transition is recognizable in the creation of protected areas: the rate increased from I275 parks per year between UNCHE and the Stockholm +Io summit (in I982) to 22I3 until WSSD. Curves may also show different stages of environmental policy. For instance, the first efforts of establishing environmental ministries were followed by the creation of protected areas, which cannot also continue indefinitely, and the signature of environmental agreements requires the existence of issues not properly covered by existing treaties. Conca (2007, p. I29) and D'Amato and Engel (I997, p. 7) suggest that governments nowadays privilege 'soft law' instead of 'hard law' as a way to 'maximize flexibility and minimize binding', which may also explain the declining numbers of environmental treaties signed per year since 1994. In addition, there is an excessive proliferation of treaties and a fragmentation of international bodies, which are in part to blame for implementation difficulties of the environmental agenda (UNEP, 2007, pp. 376-378; WRI, 2003, p. I4I).

Despite these possible confounding factors and the fact that the curves do not always follow each other's trends, they do form a pattern of four main periods of growth and decline: a first period of 'starting up' growth until around 1979 (three out of four indicators); a second period of stagnation or even recession between ig80 and I986 (three out of four indicators); a third period of steep growth between I987 and I995 (four out of four indicators) and a final period of decline since I995, although interrupted by a short peak around 2000 (five out of five indicators). Data are valid until 2006, from when no conclusions can be drawn.

These conclusions are supported by qualitative assessments of environmental policy and awareness made by Conca (2007), by the brief environmental sociology presented by Röpke (2005, p. 268) and by the deep perspective of the Portuguese philosopher Soromenho-Marques (2003, 2005, pp. 46-47). All of them propose periods of growth and decline in political activity that differ only slightly from the time intervals above.

Interestingly, peaks in the curves of Figure I occur in stages of higher concentration of the political milestones identified in Table I, particularly with the decennial Earth Summits. The first of them, around I973, coincides with the UNCHE, with three agreements (WHC, CITES and the Convention for the Prevention of Pollution from Ships) and with the creation of UNEP; the second peak, around I992, coincides with UNCED, with two agreements (CBD and UNFCCC), with the creation of UNCSD and with the approval of Agenda 2I; last, the peak around 2000-200I coincides with two conferences (the Millennium Summit and WSSD) and with two agreements (the Cartagena Protocol on Biosafety and the Stockholm Convention on Persistent Organic Pollutants). As suggested by Hibbard et al. (2007) and supported by these results, major events such as the Earth Summits appear to function as catalysts of political action and multilateralism. 


\section{Themes Addressed}

The interpretation of Figure 2, which pinpoints in time the signature of the multilateral agreements registered in the Fletcher Multilaterals Database (Ginn, 2008), suggests that significant global legislative efforts started around I950 to protect biodiversity (there are only three records before this date, the first of them in I9II); developed in the mid-I960s for protecting human rights; progressed in the late I96os for waste, chemicals and pollution issues (only two sparse records before), as well as for cultural protection; began in the late I970s for sustaining ecosystems (just two distant records before) and finally started at the beginning of the I990s for governance issues, including transboundary cooperation and public participation.

Almost half $(n=348)$ of all multilateral environmental agreements registered by Mitchell (2008) attempt to protect species or manage human impacts on those species. From these, more than one-third relate to the management of fisheries, and another third deal with marine animals including whales, turtles and seals. More than half of all pollution agreements $(n=\mathrm{I} 26)$ address marine pollution, but many concentrate on lake and river pollution (Mitchell, 2003, p. 437). Over time, new agreements have progressed from focusing on 'basic' and single issues, such as pollution prevention and conservation of certain species, to more complex and integrated approaches, such as the conservation of entire ecosystems, the management of watersheds and the attainment of air quality standards (WRI, 2003, p. I48; D'Amato and Engel, I997, p. 4).

In a similar vein, the agendas, goals and targets of political milestones have been evolving. In order to facilitate meaningful comparisons, Table 3 summarizes the achievements of selected initiatives and classifies them into main topics. These resemble the traditional three pillars that are commonly referred to as the dimensions of sustainable development (the Johannesburg Declaration on Sustainable Development, for instance, adopts the pillars of economic development, social development and environmental protection).

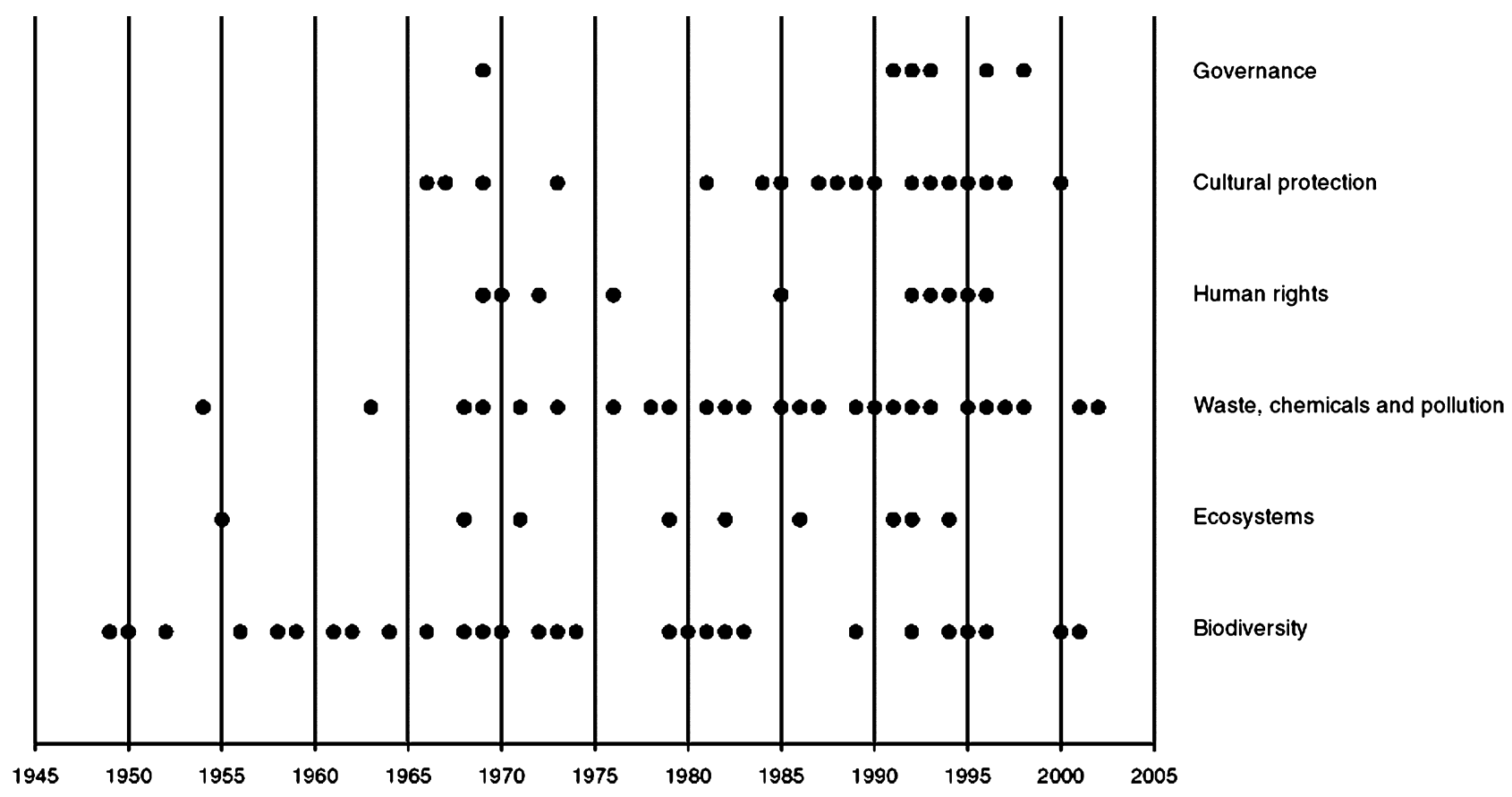

Figure 2. Thematic representation of international multilateral agreements. Source: own work based on the Fletcher database (Ginn, 2008) 


\begin{tabular}{|c|c|c|c|c|c|}
\hline $\begin{array}{l}\text { Sustainability } \\
\text { milestone }^{1}\end{array}$ & $\begin{array}{l}\text { Sustaining natural } \\
\text { capital and life support } \\
\text { systems }\end{array}$ & $\begin{array}{c}\text { Minimizing } \\
\text { human impacts }\end{array}$ & $\begin{array}{l}\text { Developing human } \\
\text { and social capital }\end{array}$ & $\begin{array}{l}\text { Developing economy } \\
\text { and institutions }\end{array}$ & Other general outputs \\
\hline $\begin{array}{l}\text { UNCHE } \\
\quad(1972)\end{array}$ & $\begin{array}{l}\text { (A) Biodiversity } \\
\text { (A) Soil erosion } \\
\text { (A) Deforestation }\end{array}$ & $\begin{array}{l}\text { (A) Ozone } \\
\text { depletion } \\
\text { (A) Air and water } \\
\text { pollution } \\
\text { (A) Household, } \\
\text { hazardous } \\
\text { and } \\
\text { radioactive } \\
\text { waste } \\
\text { (A) Global } \\
\text { warming } \\
\text { Population } \\
\text { growth }\end{array}$ & & $\begin{array}{l}\text { (A) Rapid } \\
\text { industrialization } \\
\text { (A) Cooperation on } \\
\text { environment and } \\
\text { development } \\
\text { (I) UNEP }\end{array}$ & $\begin{array}{l}\text { (D) Stockholm } \\
\text { Declaration } \\
\text { (26 principles) } \\
\text { (D) Stockholm Action } \\
\text { Plan (109 } \\
\text { recommendations) } \\
\text { (D) Five resolutions }\end{array}$ \\
\hline WCED (1987) & (A) Resources & $\begin{array}{l}\text { (A) Population } \\
\text { growth }\end{array}$ & (G) Meet basic needs & $\begin{array}{l}\text { (A) Growth } \\
\text { (A) Quality of } \\
\text { growth } \\
\text { (A) Technology } \\
\text { (A) Risk } \\
\text { (A) International } \\
\text { cooperation } \\
\text { (G) Green economy } \\
\text { (T) } 5 \text { to 10-fold more } \\
\text { growth }\end{array}$ & $\begin{array}{l}\text { (D) 'Our common } \\
\text { future' } \\
\text { (T) Achieve sustainable } \\
\text { development by } \\
2000\end{array}$ \\
\hline $\begin{array}{l}\text { United } \\
\text { Nations } \\
\text { Millennium } \\
\text { Declaration } \\
(2000)\end{array}$ & $\begin{array}{l}\text { (G) Respect for nature } \\
\text { (G) Protect common } \\
\text { environment }\end{array}$ & & $\begin{array}{l}\text { (G) Tolerance } \\
\text { (G) Peace } \\
\text { (G) Freedom } \\
\text { (G) Security } \\
\text { (G) Disarmament } \\
\text { (G) Human rights } \\
\text { (G) Equality } \\
\text { (G) Poverty } \\
\text { eradication } \\
\text { (G) Solidarity } \\
\text { (G) Protect the } \\
\text { vulnerable }\end{array}$ & $\begin{array}{l}\text { (G) Democracy } \\
\text { (G) Good } \\
\text { governance } \\
\text { (G) Shared } \\
\text { responsibility } \\
\text { (G) Strengthen the } \\
\text { United Nations }\end{array}$ & \\
\hline
\end{tabular}




\begin{tabular}{|c|c|c|c|c|}
\hline WSSD (2002) & $\begin{array}{l}\text { (A) Biodiversity } \\
\text { (A) Water } \\
\text { (T) Significantly } \\
\text { reducing the rate of } \\
\text { biodiversity loss by } \\
2010 \\
\text { (T) Returning fisheries } \\
\text { to maximum } \\
\text { sustainable yield } \\
\text { levels by } 2015\end{array}$ & $\begin{array}{l}\text { (A) Health } \\
\text { (A) Sanitation } \\
\text { (T) Halve, between } \\
1990 \text { and } 2015 \text {, } \\
\text { the proportion of } \\
\text { people whose } \\
\text { income is }<\$ 1 \text { a } \\
\text { day } \\
\text { (T) Between 1990 } \\
\text { and } 2015 \text { reduce } \\
\text { by } 2 / 3 \text { the }<5 \\
\text { mortality rate } \\
\text { (T) By } 2015 \text { halt and } \\
\text { begin to reverse } \\
\text { the spread of } \\
\text { AIDS } \\
\text { (T) Halve, by } 2015 \text {, } \\
\text { the proportion of } \\
\text { people without } \\
\text { access to safe } \\
\text { drinking water } \\
\text { (T) Achieve, by } 2020 \text {, } \\
\text { a significant } \\
\text { improvement to } \\
\text { the lives of at } \\
\text { least } 100 \text { million } \\
\text { slum dwellers }\end{array}$ & $\begin{array}{l}\text { (A) Energy } \\
\text { (A) Agriculture } \\
\text { (A) Institutions for } \\
\text { sustainability }\end{array}$ & $\begin{array}{l}\text { (D) Johannesburg } \\
\text { Declaration } \\
\text { (37 principles) } \\
\text { (D) Johannesburg Plan } \\
\text { of Implementation } \\
\text { (170 paragraphs) }\end{array}$ \\
\hline
\end{tabular}

Table 3. Comparison of sustainable development agendas, goals and targets as expressed in selected conferences, declarations and publications. The table draws from Leiserowitz et al. (2006), Selin and Linnér (2005), Soromenho-Marques (2003, 2005) and Kirkby et al. (1999)

' (A) topic of the agenda; (D) declaration; (G) goal; (M) multilateral agreement; (I) institution; (T) target.

\section{Conclusions}

The present paper aimed at revealing the main developments and cycling patterns of political activity concerning sustainable development, and at identifying the most important sustainability goals and targets. The cycling patterns of Figure I combined with the uneven time distribution of the milestones identified in Table I convey the powerful message that political efforts are indeed characterized by measurable ups and downs. Moreover, the fact that the peaks in political activity coincide with the decennial Earth Summits (particularly UNCED and WSSD, and to a lesser degree UNCHS) is suggestive of their influence as catalysts of more profound societal and political action.

In a first 'starting up' stage until the I970s, the first significant efforts for environmental protection were undertaken. At the national level, governments started to approve general legislative frameworks, to establish environmental ministries and to create protected areas. At the global and regional scales, multilateral treaties aiming at the conservation of species (CITES) and ecosystems (Ramsar Convention), the protection of human rights and cultural heritage (WHC) and the control of pollution (CLRTAP) were agreed. The Stockholm Conference in I972 was a recognizable milestone and resulted in the creation of UNEP.

A second stage characterized by a stagnation of sustainable development policy followed and extended until around i986. Although at the national level the creation of protected areas continued to grow, multilateral efforts in the environmental area refrained due to a shift for economic prosperity as a solution for development problems. Besides this less favorable atmosphere, the WCS (in I980) gave visibility to the concept of sustainable development. However, the concept appears for the first time with a meaning similar to the one coined in 1987 by the 
Brundtland Commission in 1976 (in text of the Agreement Establishing the South Pacific Regional Environment Programme, according to a search in Mitchell, 2008).

The decade from around I987 until I995 represents another period of significant efforts of the international community to push for sustainable development. The Brundtland Commission set the stage in their report Our Common Future. Sustainable development definitely entered the lexicon and became a popular expression, receiving the agreement of almost everyone. The 1992 UNCED is another obvious breakthrough, as supported by peaks in all indicators of Figure 3 around this date and by the impressive number of political milestones that followed: environmental agreements (CBD, UNFCCC), institutional arrangements and financial mechanisms (CSD, GEF) and acknowledged 'soft law' (Rio Declaration, Agenda 2I). The balanced position offered by WCED was neglected during UNCED, whose agenda was significantly 'greener'. During the I990s, governance issues such as transboundary cooperation and public participation were finally addressed by multilateral agreements.

The fourth period, which started around I996, is marked by a decline in global sustainable development policy. The fear of terrorism and the globalization of economy are probable reasons, but a short peak in political indicators around 2000 - certainly related to the coming of WSSD - make the conclusions less straightforward. But even WSSD as a milestone was not as influential as UNCED, if the judgment is based on their outcomes (Table 3). For instance, no agreements, institutional arrangements or financial mechanisms followed WSSD; and although several targets were approved, Röpke (2005) remarks on a notable 'implementation deficit' that the international community seems unable to counteract. As already proposed by UNEP (2007, p. 376), perhaps a new stage of sustainable development policy is emerging that shifts its attention to the implementation of existing norms and policies, including the growing number of national sustainable development strategies, which already amount to 82 (UNDSD, 2008a).

Topics and goals addressed at the global level by multilateral agreements and by other political milestones have been in constant evolution, depending on the perception of which problems require primary attention, on disasters or specific events that trigger immediate responses and on influences from the scientific realm. Analysis of Table 3 reveals a transition from single issues to more complex and integrated frameworks. Ecosystem concerns succeeded species conservation initiatives, and it was not until the I990s that governance issues were directly addressed by MEA. Since 2000 , this interest in the institutional dimension of sustainable development seems to be continuing, at least in the discourse of the Millennium Declaration and of WSSD, although it is not accompanied by implementation mechanisms. It is also visible that treaties have been approved in recent times to regulate new topics that pose specific threats such as genetically modified organisms and persistent organic pollutants. Several targets have been agreed by the international community, namely through the Millennium Development Goals. These commitments are meritorious but at the same time biased towards human development, since these are significantly more detailed and in a larger number than the environmental protection goals. Sustainability concerns shifted from an emphasis on pollution and availability of natural resources to a more balanced position that puts human and social development - particularly freedom and the expansion of individual capacities - at the center.

As a final synthesis regarding which goals and topics are most relevant in the context of sustainable development, a new set of six main policy pillars is proposed to substitute the traditional three pillar approach, which seems to be of limited capacity to encompass the variety of sustainability issues:

- sustaining natural capital - biodiversity, water, air;

- sustaining life support systems - ecosystems, ecosystem services, resources;

- minimizing human impacts - climate change, pollution, waste, desertification, population growth;

- developing human capital - human rights, political liberties, learning, equity, health, wealth;

- developing social capital - solidarity, community, culture;

- developing economy - economy, agriculture, consumption, employment, technology;

- developing institutions - good governance, democracy, transparency, public participation, international cooperation.

Sustainable development governance has grown immensely during the last 40 years. A number of institutions, treaties, laws and strategies have been devised to pursue a multitude of goals that range from protecting species 
and their ecosystems to ensuring and expanding human rights. One of the greatest challenges now is how to set up a new stage of policy and transform the meritorious ideas and goals of sustainability into reality.

\section{References}

Adams WM. 2006. The Future of Sustainability: Re-Thinking Environment and Development in the Twenty-First Century. IUCN: Zurich.

Conca K. 2007. Environmental governance after Johannesburg: from stalled legalization to environmental human rights. Journal of International Law and International Relations I: $\mathrm{I} 2 \mathrm{I}-\mathrm{I} 38$.

Daly H. I996. Beyond Growth: the Economics of Sustainable Development. Beacon: Boston, MA.

D’Amato A, Engel K. I997. International Environmental Law Anthology. Andersen: Cincinnati, OH.

Dasgupta P. 200I. Human Well-Being and the Natural Environment. Oxford University Press: Oxford.

Ginn E. 2008. Fletcher Multilaterals Database. http://fletcher.tufts.edu/multi/multilaterals.html [I7 December 2008].

Goodland R. I995. The concept of environmental sustainability. Annual Review of Ecology and Systematics 26: I-24.

Haas PM. 2004. Addressing the global governance deficit. Global Environmental Politics 4: I-I5.

Helm C, Sprinz D. 2000. Measuring the effectiveness of international environmental regimes. Journal of Conflict Resolution 44(5): 630-652.

Hibbard KA, Crutzen PJ, Lambin EF, Liverman DM, Mantua NJ, McNeill JR, Messerli B, Steffen W. 2007. Group report: decadal-scale interactions of humans and the environment. In Sustainability or Collapse? An Integrated History and Future of People on Earth, Costanza R, Graumlich L, Steffen W (eds). MIT Press: Cambridge; 34I-375.

International Institute for Sustainable Development (IISD). 2007. The Sustainable Development Timeline. http://www.iisd.org/pdf/2007/ sd_timeline_2007.pdf [I7 December 2008].

Kates RW, Parris TM. 2003. Long-term trends and a sustainability transition. Proceedings of the National Academy of Sciences of the United States of America Ioo(I4): 8062-8067.

Kates R, Parris T, Leiserowitz A. 2005. What is sustainable development: goals, indicators, values and practice. Environment 43(3): 9-2I.

Kirkby J, O’Keefe P, Timberlake L. I999. Sustainable development: an introduction. In The Earthscan Reader in Sustainable Development, Kirkby J, O'Keefe P, Timberlake L (eds). Earthscan: London; I-I4.

Leiserowitz AA, Kates RW, Parris TM. 2006. Sustainability values, attitudes, and behaviors: a review of multinational and global trends. Annual Review of Environment and Resources 31: 413-444.

Miles E, Underdal A, Andresen S, Wettestad J, Skjaerseth JB, Carlin EM. 200I. Environmental Regime Effectiveness: Confronting Theory with Evidence. MIT Press: Cambridge.

Millennium Ecosystem Assessment (MEA). 2005. Ecosystems and Human Well-Being: Synthesis. Island: Washington, DC.

Mitchell RB. 2003. International environmental agreements: a survey of their features, formation, and effects. Annual Review of Environment and Resources 28: 429-46I.

Mitchell RB. 2006. Part two: The effectiveness of international environmental regimes - problem structure, institutional design, and the relative effectiveness of international environmental agreements. Global Environmental Politics 6(3): 72-88.

Mitchell RB. 2008. International Environmental Agreements Database Project. http://iea.uoregon.edu [I7 December 2008].

Morse S. 2008. Post-sustainable development. Sustainable Development I6(5): 34I-352.

Organization for Economic Co-Operation and Development (OECD). 2008. OECD.Stat. http://stats.oecd.org [I7 December 2008].

Parris TM, Kates RW. 2003a. Characterizing a sustainability transition: goals, targets, trends, and driving forces. Proceedings of the National Academy of Sciences of the United States of America Ioo(I4): 8068-8073.

Parris TM, Kates RW. 2003b. Characterizing and measuring sustainable development. Annual Review of Environment and Resources 28: 559586.

Pawlowski A. 2008. How many dimensions does sustainable development have? Sustainable Development I6(2): 8I-90.

Redclift MR. 2006. Sustainable development (1987-2005): an oxymoron comes of age. Sustainable Development 12: 65-84.

Röpke I. 2005 . Trends in the development of ecological economics from the late I980s to the early 2000s. Ecological Economics $55(2)$ : $262-$ 290.

Runyan C, Norderhaug M. 2002. The path to Johannesburg. World Watch 15(3): 30-35.

Selin H, Linnér BO. 2005. The Quest for Global Sustainability: International Efforts on Linking Environment and Development, Center for International Development graduate student and postdoctoral fellow working paper, Vol. 5. CID, Harvard University: Cambridge.

Skowronski A. 2008. A civilization based on sustainable development: its limits and prospects. Sustainable Development I6(2): II7-I25.

Soromenho-Marques V. 2003. Globalisation, Risk, and International Environmental Policy. http://www.viriatosoromenho-marques.com/Imagens/ PDFs/Globalization\%2oand\%20Environment,\%20Cascais,\%202003.pdf [25 February 2009].

Soromenho-Marques V. 2005. Metamorfoses: entre o Colapso e o Desenvolvimento Sustentável. Publicações Europa-América: Mem Martins.

Underdal A, Young O (eds). 2004. Regime Consequences: Methodological Challenges and Research Strategies. Kluwer: Dordrecht.

United Nations Division for Sustainable Development (UNDSD). 2008a. National Sustainable Development Strategies: the Global Picture. http://www.un.org/esa/sustdev/natlinfo/nsds/nsds_map2008.pdf [I7 December 2008].

United Nations Division for Sustainable Development (UNDSD). 2008b. Partnerships for Sustainable Development. http://www.un.org/esa/ sustdev/partnerships/partnerships.htm [I7 December 2008].

United Nations Environment Programme (UNEP). 200I. Multilateral Environmental Agreements: a Summary. United Nations Environment Programme: New York. 
United Nations Environment Programme (UNEP). 2002. Global Environment Outlook 3. Earthscan: London.

United Nations Environment Programme (UNEP). 2007. Global Environment Outlook 4: Environment for Development. Progress: Valletta.

United Nations Environment Programme (UNEP). 2008. UNEP Milestones. http://www.unep.org/Documents.Multilingual/Default. asp? DocumentID=287 [I7 December 2008].

United Nations Environment Programme (UNEP), International Union for Conservation of Nature (IUCN). 2007. World Database on Protected Areas. http://www.wdpa.org [I7 December 2008].

Wapner P. 2003. World Summit on Sustainable Development: toward a post-Jo'burg environmentalism. Global Environmental Politics 3(I): I-IO.

World Commission on Environment and Development (WCED). I987. Our Common Future. Oxford University Press: Oxford.

World Resources Institute (WRI). 2003. World Resources 2002-2004: Decisions for the Earth. World Resources Institute: Washington, DC.

World Resources Institute (WRI). 2007. EarthTrends: Environmental Information. http://earthtrends.wri.org [I7 December 2008].

Young O. 1999. The Effectiveness of International Environmental Regimes: Causal Connections and Behavioral Mechanisms. MIT Press: Cambridge. 